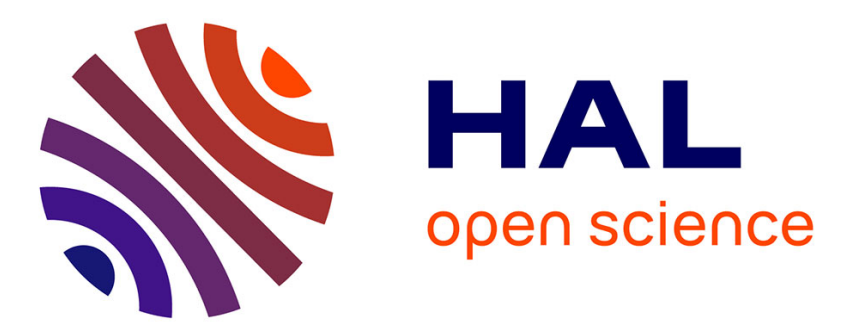

\title{
Comparison of manure compost and mineral fertilizer for hybrid poplar plantation establishment on boreal heavy clay soils
}

\author{
Rémi Larchevèque, Desrochers, Guy Larocque
}

\section{To cite this version:}

Rémi Larchevèque, Desrochers, Guy Larocque. Comparison of manure compost and mineral fertilizer for hybrid poplar plantation establishment on boreal heavy clay soils. Annals of Forest Science, 2011, 68 (4), pp.849-860. 10.1007/s13595-011-0081-3 . hal-00930814

HAL Id: hal-00930814 https://hal.science/hal-00930814

Submitted on 1 Jan 2011

HAL is a multi-disciplinary open access archive for the deposit and dissemination of scientific research documents, whether they are published or not. The documents may come from teaching and research institutions in France or abroad, or from public or private research centers.
L'archive ouverte pluridisciplinaire HAL, est destinée au dépôt et à la diffusion de documents scientifiques de niveau recherche, publiés ou non, émanant des établissements d'enseignement et de recherche français ou étrangers, des laboratoires publics ou privés. 


\title{
Comparison of manure compost and mineral fertilizer for hybrid poplar plantation establishment on boreal heavy clay soils
}

\author{
Marie Larcheveque • Annie Desrochers • \\ Guy R. Larocque
}

Received: 14 September 2010 / Accepted: 20 December 2010/Published online: 31 May 2011

(C) INRA and Springer Science+Business Media B.V. 2011

\begin{abstract}
- Introduction Clay soils are typically rich in nutrients but are often compact and hard during summer increasing planting shock by limiting root development. Recycling farm manure in hybrid poplar plantations may offer additional benefits to mineral fertilizer as organic amendment can create better conditions for the early development of roots in addition to nutrient release.

- Material and methods Composted sheep manure (10 and $20 \mathrm{~kg} /$ tree) at planting was compared to $\mathrm{N}$ and $\mathrm{P}$ mineral fertilization ( $15 \mathrm{~g} 34.5-0-0$ with $15 \mathrm{~g} 0-45-0$, provided by

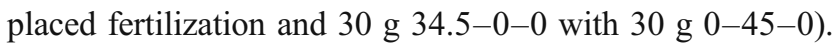
- Results The highest dose of mineral fertilization was the most efficient approach to increase poplar growth (height, diameter, biomass, leaf, and root development) for the three tested clones. However, trees were more water stressed with less negative $\delta^{13} \mathrm{C}$ in leaves the second year of growth.

- Discussion Contrary to what we expected, compost treatments neither increased root development nor tree water status even if they succeeded in improving soil water-
\end{abstract}

Handling Editor: Gilbert Aussenac

M. Larcheveque $(\bowtie) \cdot$ A. Desrochers

Université du Québec en Abitibi-Témiscamingue,

Chaire Industrielle CRSNG-UQAT-UQAM en Aménagement

Forestier Durable,

341 Principale Nord,

Amos, QC J9T 2L8, Canada

e-mail: marie.larcheveque@uqat.ca

G. R. Larocque

Natural Resources Canada, Canadian Forest Service,

Laurentian Forestry Centre,

1055 du P.E.P.S., P.O. Box 10380, Stn. Sainte-Foy,

Quebec, QC G1V 4C7, Canada holding properties. This may be due to the type of planting stock (rootstock with pruned stems), which reduce water stress by synchronizing leaf and root development, or to compost high maturity and slow mineralization rate under boreal climate. However, compost manure also gave positive growth benefits and could represent a cheaper alternative to synthetic fertilizers in the vicinity of animal feedlots.

Keywords Fast-growing plantation · Growth · Root development $\cdot$ Soil water-holding capacity $\cdot$ Water stress

\section{Introduction}

The establishment of fast-growing plantations is increasing around the world to meet the demand for industrial wood (Food and Agriculture Organization of the United Nations 2009). Even in forested countries such as Canada, these plantations can contribute to decreasing the harvesting pressure on natural forests. Hybrid poplars (Populus spp.) are among the favorite species for use in plantations because of their ease of multiplication, high production, and valuable wood and fiber (Dickmann et al. 2001). To reach expected yields, successful and rapid tree establishment is required in order to reduce rotation length and decrease maintenance costs by shading out weeds sooner. Hardwood bareroot seedlings typically undergo planting shock at planting due to moisture or nutrient stresses (DesRochers and Tremblay 2009), which can decrease productivity of the plantation for several years (Grossnickle 2005). The resulting growth stagnation usually corresponds to the time needed by the trees to grow an adequate root system for the site where they are planted (Grossnickle 2005). Moreover, in regions where the growing season is 
short, rapid tree establishment is necessary to avoid frost or drought damages and reduce grass competition.

Clay and heavy clay soils are often compact and hard making it difficult for the roots to grow and penetrate (DesRochers and Tremblay 2009) during dry periods. Even though these soils are typically rich in nutrients, limited root development may reduce nutrient uptake. In clay soils, fertilization at planting can enhance growth significantly by increasing nutrient availability to roots, especially for nutrient demanding hybrid poplars (van den Driessche 1999). In the boreal clay belt of Quebec and Ontario, it was possible to nearly double hybrid poplar growth within the first two growing seasons with only moderate mineral fertilization (Guillemette and DesRochers 2008).

The use of organic farm wastes such as animal manure in plantations on former arable lands could be an alternative to industrial fertilizers and could provide an interesting recycling solution for farmers. It may offer additional benefits to mineral fertilizers by reducing planting shock since it can also improve soil structure and, consequently, create better conditions for root development (porosity, aeration, and water-holding capacity; Pagliali et al. 1981) in addition to nutrient release (Larchevêque et al. 2006a, b). Higher yields are generally reached in plantations amended with composts, which are rich in organic matter, compared to mineral fertilizers (Adegbidi et al. 2003). By slowly releasing nutrients, composts could extend fertilization effects compared to mineral fertilizers and prevent nutrient leaching.

Because of their high maintenance requirements, hybrid poplar plantations are preferably established on abandoned farmlands, as these sites are easy to cultivate and often closer to populations and mills. Organic amendments should be especially effective on such sites where previous agricultural use may have induced soil compaction, often leading to a decrease in soil permeability, air circulation, available rooting space, and tree productivity (Grigal 2000).

The main objective of this study was to determine if a single amendment of composted manure at planting could improve hybrid poplar establishment and early growth compared to mineral fertilization on an abandoned farmland located in the Northern Clay Belt region of Quebec and Ontario, Canada. Three fast-growing clones from different parentages, well-adapted to this boreal region, were planted and their growth, biomass, and ecophysiology monitored over two growing seasons. Compost effects on soil agronomic and structural properties were also evaluated. Our working hypotheses were that: (1) compost amendment improves root development of hybrid poplars leading to better nutrient and water acquisition; (2) compost application has a greater effect on tree growth and nutrition than mineral amendments; (3) as compost has a better waterretention capacity, it improves tree water status.

\section{Material and methods}

\subsection{Site description}

The plantation was established on a typical abandoned farmland in the Abitibi-Témiscamingue region of northwestern Quebec, Canada near the locality of Ste-Gertrude $\left(48^{\circ} 32^{\prime} \mathrm{N}-78^{\circ} 22^{\prime} \mathrm{O}\right)$. This area is located in the Northern Clay Belt region of Quebec and Ontario, a large ecological region created by lacustrine deposits from the maximum post-Wisconsinian extension of postglacial lakes Barlow and Ojibway. These acid soils are usually compact and hard during dry periods and very soft and clumpy during rainy periods. Soil characteristics before amendment are presented in Table 1. The growing season begins in mid-May and ends in early October with a mean temperature during the three warmest months (June, July, and August) around $18-19^{\circ} \mathrm{C}$. Average annual temperature is $1{ }^{\circ} \mathrm{C}$, and the average number of frost-free days is 80 . Mean annual precipitations vary around $900 \mathrm{~mm}$ (Environment Canada 2004). Typical forest vegetation surrounding agricultural fields includes jack pine (Pinus banksiana Lamb.), black spruce (Picea mariana (Mill.) Britton), trembling aspen (Populus tremuloides Michx.), white birch (Betula papyrifera Marsh.), and balsam fir (Abies balsamea (L.) Mill.). Prior to planting, the plantation site was essentially colonized by grasses and site preparation consisted of agricultural plowing (autumn 2007, $20 \mathrm{~cm}$ deep) followed by repeated disking (spring 2008, 20-25 cm deep) to level the soil and remove lumps. After planting, weeds were mechanically removed twice a year (mid-July and midSeptember) by disking in between rows and trees.

\subsection{Compost and mineral fertilizers}

Sheep manure was locally produced (Rivest farm, Amos, QC, Canada) and composted in aerobic conditions during 2 years in a reversed pile before use. Manure compost was manually applied a few days before plantation on a $1-\mathrm{m}^{2}$ area at two rates: $\mathrm{C} 1,10 \mathrm{~kg}$ of fresh matter (FM)/tree or $11 \mathrm{t} \mathrm{FM/ha} \mathrm{and} \mathrm{C2,} 20 \mathrm{~kg} \mathrm{FM} /$ tree. It was mixed with the top soil $(10 \mathrm{~cm}$ deep $)$ to improve the effect on soil structure. The trees were then planted in the center of the $1-\mathrm{m}^{2}$ amended areas. The compost application rates were calculated to provide equivalent mineral $\mathrm{N}$ and $\mathrm{P}$ quantities as mineral fertilizer rates that were shown to be efficient on similar sites previously fertilized (Guillemette and DesRochers 2008). Two mineral fertilization rates were compared with compost treatments: M1, 15 g ammonium nitrate (34.5$0-0)$ with $15 \mathrm{~g}$ triple superphosphate $(0-45-0)$, and M2, $30 \mathrm{~g}$ ammonium nitrate (34.5-0-0) with $30 \mathrm{~g}$ triple superphosphate $(0-45-0)$. The mineral fertilizers were 
Table 1 Initial soil and compost characteristics in June 2008

\begin{tabular}{|c|c|c|c|c|c|}
\hline Parameter & $\begin{array}{l}\text { Soil(fraction } \\
<2 \mathrm{~mm})\end{array}$ & Compost & $\begin{array}{l}\text { C1 rate } \\
\left(\mathrm{g} \text { tree }{ }^{-1}\right)\end{array}$ & $\begin{array}{l}\text { Quantity in soil } \\
\text { before amendment }(\mathrm{g})\end{array}$ & $\begin{array}{l}\text { Percent of increase } \\
\text { in soil }(0-10 \mathrm{~cm}) \\
\text { calculated for } \mathrm{C} 1 \text { rate }\end{array}$ \\
\hline Density $\left(\mathrm{g} \mathrm{cm}^{-3}\right)$ & $1.0(0.005)$ & $0.44(0.03)$ & & & \\
\hline Clay $(\%)$ & $29(0.9)$ & & & & \\
\hline Granulometry silt (\%) & $22(1.1)$ & & & & \\
\hline Sand $(\%)$ & $49(1.4)$ & & & & \\
\hline Texture & Sandy, clay, loam & & & & \\
\hline $\begin{array}{l}\text { Estimated cation exchange capacity } \\
\left.\text { (méq. } 100 \mathrm{~g}^{-1} \mathrm{DM}\right)\end{array}$ & $14(1.5)$ & $86(0.6)$ & & & \\
\hline Humidity $(\% \mathrm{FM})$ & & $69.3(1.4)$ & & & \\
\hline pH (SMP buffer) & $5(0.01)$ & $7.5(0.02)$ & & & \\
\hline $\mathrm{C} / \mathrm{N}$ & 11 & 9.2 & & & \\
\hline Organic matter $(\% \mathrm{DM})$ & $5(0.2)$ & $46(0.3)$ & 1,412 & 5,000 & 28 \\
\hline Total N (\% DM) & $0.27(0.01)$ & $2.9(0.1)$ & 89 & 270 & 33 \\
\hline NO3 $-\left(\mathrm{mg} \mathrm{kg}^{-1} \mathrm{DM}\right)$ & & $466(64)$ & 1.4 & & \\
\hline $\mathrm{NH} 4+\left(\mathrm{mg} \mathrm{kg}^{-1} \mathrm{DM}\right)$ & & $54(19)$ & 0.2 & & \\
\hline Total P (\% DM) & $0.05(0.001)$ & $1.1(0.17)$ & 34 & 50 & 68 \\
\hline Available $\mathrm{P}\left(\mathrm{mg} \mathrm{kg}^{-1} \mathrm{DM}\right)$ & & $1,593(347)$ & 4.9 & & \\
\hline Total K (\% DM) & $0.55(0.01)$ & $1.8(0.07)$ & 55 & 550 & 10 \\
\hline Exchangeable $\mathrm{K}\left(\mathrm{mg} \mathrm{kg}^{-1} \mathrm{DM}\right)$ & & $15,190(3,805)$ & 47 & & \\
\hline Total Mg (\% DM) & $1.4(0.01)$ & $1.2(0.06)$ & 37 & 1,400 & 3 \\
\hline Exchangeable $\mathrm{Mg}\left(\mathrm{mg} \mathrm{kg}^{-1} \mathrm{DM}\right)$ & & $2,270(446)$ & 7 & & \\
\hline Total Ca (\% DM) & $0.52(0.01)$ & $2.9(0.2)$ & 89 & 520 & 17 \\
\hline Exchangeable $\mathrm{Ca}\left(\mathrm{mg} \mathrm{kg}^{-1} \mathrm{DM}\right)$ & & $4,838(775)$ & 15 & & \\
\hline
\end{tabular}

Mean (SE), soil $(N=20-35)$, compost $(N=3-5) ; D M$ dry matter, $F M$ fresh matter

provided by placed fertilization (van den Driessche 1999), which consisted in inserting fertilizer into a slit made with a spade at the base of each tree $(20 \mathrm{~cm}$ from the tree and $15 \mathrm{~cm}$ deep). Both compost and mineral fertilizer rates aimed at providing $\mathrm{N}$ and $\mathrm{P}$ to planted trees for 1-2 years after planting. Table 1 shows the compost characteristics and calculated rates of nutritional elements brought by compost at rate $\mathrm{C} 1$. A control treatment, without any fertilization, was also implemented.

\subsection{Tree material}

Three hybrid poplar clones locally produced by the Ministère des RessourcesNaturelles et de la Faune du Québec were planted in mid-June 2008. Hybrid poplar stock (2-0) consisted of dormant bare-root trees with no leaf formation: Populus balsamifera $\times$ Populus maximowiczii $(\mathrm{B} \times \mathrm{M}$, clone 915005), P. maximowiczii $\times$ P. balsamifera $(\mathrm{M} \times \mathrm{B}$, clone 915319), and Populus deltoides $\times P$. balsamifera $(\mathrm{D} \times \mathrm{B}$, clone 3389$)$. Shoots were pruned at planting (cut $15 \mathrm{~cm}$ above the root collar) and planted flush with the ground level to avoid root/shoot imbalances and associated stem dieback (Guillemette and DesRochers
2008) without compromising early growth rates (DesRochers and Tremblay 2009).

\subsection{Experimental design}

The experiment was set up as a split-plot design with four blocks (replicates) $\times$ five fertilization treatments (two compost rates $\mathrm{C} 1$ and $\mathrm{C} 2$, two mineral fertilizer rates, $\mathrm{M} 1$ and $\mathrm{M} 2$, and a control, $\mathrm{T}) \times$ three clones $(\mathrm{BxM}, \mathrm{MxB}$, and $\mathrm{DxB}) \times$ nine trees per factor combination (pseudoreplicates). This split-plot design was chosen to avoid compost contamination of non-amended plots. Indeed, each zone devoted to one fertilization treatment was surrounded by a $6-\mathrm{m}$ buffer zone without trees. The poplar clones were planted at a $3 \times 3-\mathrm{m}$ spacing on $6 \times 6-\mathrm{m}$ plots (nine trees), which corresponded to a density of 1,111 trees $\mathrm{ha}^{-1}$.

2.5 Measurements, sampling, and analysis

\subsubsection{Compost}

Five random samples were taken from the compost pile before amendment to measure bulk density and water 
content. Nutrient analyses were conducted on three dried samples $\left(50^{\circ} \mathrm{C}\right)$, except for mineral $\mathrm{N}$ which was analyzed on fresh frozen subsamples (Center for Analytical Service at Lakehead University, ON, Canada). Nutrient analyses (compost, but also soil) were performed on oven-dried $\left(50^{\circ} \mathrm{C}\right), 2-\mathrm{mm}$ sieved, and finely ground samples. Total $\mathrm{C}, \mathrm{N}$, and organic $\mathrm{C}$ were analyzed by combustion (LECO CNS 2000, Mississauga, $\mathrm{ON}$, Canada). For total $\mathrm{P}, \mathrm{K}, \mathrm{Ca}$, and $\mathrm{Mg}$, samples were digested by nitric and hydrochloric acids and measured by inductively coupled plasma atomic emission spectrometry (ICP-AES). Available P was determined in a sodium bicarbonate solution using spectrophotometry. Exchangeable $\mathrm{K}, \mathrm{Ca}, \mathrm{Mg}$, and $\mathrm{Na}$ were $1 \mathrm{M} \mathrm{NH}_{4} \mathrm{Ac}$ extracted and determined by ICP-AES. Cationic exchange capacity was then estimated. Available $\mathrm{NH}_{4}{ }^{+}$and $\mathrm{NO}_{3}{ }^{-}$ were extracted by $\mathrm{KCl}(2 \mathrm{M})$ and determined by continuous flow analysis (Technicon Autoanalyzer II). Finally, $\mathrm{pH}$ was determined in saturated paste extract.

\subsubsection{Soil}

Soil characteristics were measured in each fertilization treatment (four blocks $\times$ five treatments $=20$ samples), before amendment (May 2008), then again in August 2008 and July 2009 but only on T, C1, and C2 fertilization treatments (four blocks $\times$ three treatments $=$ 12 samples). For nutrient and texture analyses, soil samples from the top $15 \mathrm{~cm}$ were collected from each treatment $\times$ clone combination. Composite samples per fertilization treatment were made with the three samples corresponding to the three clones for one treatment. Soil texture was determined on the samples taken before amendment using the Bouyoucos hydrometer method.

For soil structure, undisturbed $100 \mathrm{~cm}^{3}$ soil samples were taken with a double-cylinder soil sampler at $0-10$ depth, $20 \mathrm{~cm}$ away from one tree per treatment combination (fertilization $\times$ clone) to measure bulk density and field capacity. Samples were taken at the same depths for permanent wilting point measurements (August 2008 and July 2009 only). Water-retention properties were determined following Cassel and Nielsen (1986) procedures by using the porous surface of a sand box apparatus (field capacity, Eijkelkamp Agrisearch Equipment) and a pressure membrane apparatus (permanent wilting point; Soil Moisture Equipment Corp).

\subsubsection{Plants}

In each plot, survival, basal diameter, and stem height were measured on all trees at planting (basal diameter only) and in late-October after the first two growing seasons. A total of 120 and 105 trees per block were measured in 2008 and 2009, respectively (eight and seven pseudo-replicates per factor combination due to trees sampled for biomass measurement at the end of the first two growing seasons). In August 2009, basal diameter of the dominant shoot was also measured on trees destructively sampled for biomass.

In August 2008 and 2009, trees were harvested for biomass allocation assessment (four replicates for each factor combination, fertilization treatment $\times$ clone). Trees were separated into roots, stems, and leaves. Total leaf area was measured prior to drying with a LI-3100 C leaf area meter (LiCor, Lincoln, NE, USA). Leaf number was determined and individual leaf area calculated. The different plant parts were then oven dried at $50^{\circ} \mathrm{C}$ and weighed. Biomass allocation among the plant components was assessed by determining root mass ratio (RMR, $\mathrm{g} \mathrm{g}^{-1}$ ), stem mass ratio (SMR, $\mathrm{g} \mathrm{g}^{-1}$ ), and leaf mass ratio (LMR, $\mathrm{g} \mathrm{g}^{-1}$ ) as the ratios of root, stem, or leaf dry mass to the whole tree dry biomass. Specific leaf area (SLA, total leaf area/total leaf dry mass, $\mathrm{cm}^{2} \mathrm{mg}^{-1}$ ) and leaf area ratio (LAR, total leaf area/whole seedling dry biomass, $\mathrm{cm}^{2} \mathrm{~g}^{-1}$ ) were also calculated. All leaves were oven-dried and ground for each tree and analyzed for nutrient status with the same methods as soil and compost (total N, P, K, Ca, and Mg). In August 2009, the number and total length of adventitious roots developed on the tree shoots were assessed, as well as the biomass of the same roots with a diameter $<5 \mathrm{~mm}$.

An aliquot of leaf powder used for nutrient analyses was more finely ground with a Brinkmann MM2 ball grinder (Brinkmann Instruments Ltd., Mississauga, ON, Canada). Isotope ratios $\left({ }^{13} \mathrm{C} /{ }^{12} \mathrm{C}\right)$ were determined using a Costech ECS 4010 Elemental combustion system (Costech Analytical Technologies Inc. Valencia, CA, USA) coupled to a continuous flow Finnigan Delta Plus Advantage IRMS (ThermoFinnigan, Bremen, Germany). The relative abundance of ${ }^{13} \mathrm{C}$ in leaves was expressed in terms of carbon isotope composition $\left(\delta^{13} \mathrm{C}\right)$, according to the following relationship: $\delta^{13} C=\left[\left(R_{1}-R_{s}\right) / R_{s}\right] \times 1,000$, where $R_{1}$ and $R_{\mathrm{s}}$ refer to the ${ }^{13} \mathrm{C} /{ }^{12} \mathrm{C}$ ratio in the leaf sample and in the standards, respectively. BMO (grain), CS (corn stover), and NBS 1575 N (pine needle; NIST, Standard Reference Materials, Gaithersburg, MD, USA) were used as calibrating standards and Red Clover as working standard, with carbon isotope compositions of $-23.91 \%$, $-12.5 \%$ o, $-26.3 \%$, and $-27.42 \%$ o relative to Pee Dee Belemnite, respectively.

\subsection{Statistical analysis}

For soil structural and agronomic parameters, data were analyzed by year with one-way analysis of covariance (fertilization treatment effect; PROC GLM, SAS statistical package, V.9.1, SAS Institute Inc., Cary, NC, USA). Soil 
density, macroporosity, and field capacity measured before amendment were used as covariates with the corresponding variables in 2008 and 2009. Survival data were compared using the chi-square Mantel-Haenszel test (0.05 significance level; PROC FREQ, SAS statistical package, V.9.1, SAS Institute Inc., Cary, NC, USA). Analyses were carried out by clone for the factor fertilization treatment. For basal diameter and height, data were submitted to three-way analyses of covariance that included fertilization treatment, clone, and date effects (PROC MIXED with repeated measurements, SAS statistical package, V.9.1, SAS Institute Inc., Cary, NC, USA). Basal diameter measured at planting was used as a covariate in height and diameter analyses. For biomass and nutrients, data were analyzed by year with two-way analyses of covariance that included fertilization treatment and clone effects (PROC GLM, SAS statistical package, V.9.1, SAS Institute Inc., Cary, NC, USA). All tested factors were fixed except block, which was random. When effects were significant for a given trait, least-square means were estimated (LS MEANS statement) and Tukey tests were carried out at the 0.05 significance level.

\section{Results}

\subsection{Soil effects of compost treatments}

Compost had little effects on soil agronomic properties for both years of the experiment (Tables 2 and 3). In 2008 , total $\mathrm{N}$ concentration was greater in soil amended with compost at $\mathrm{C} 2$ rate compared to $\mathrm{C} 1$ and $\mathrm{T}$ soils (Fig. 1a). This compost effect disappeared in 2009. Total P concentration increased in amended soil at $\mathrm{C} 1$ and $\mathrm{C} 2$ in 2008 (Fig. 1b), but this compost effect was not significant neither in 2008 nor 2009 (Tables 2 and 3). However, compost at $\mathrm{C} 1$ rate increased soil exchangeable $\mathrm{K}$ in 2009 (Tables 2 and 3, Fig. 1c). On the other hand, compost improved soil water properties in 2008 with increased field capacity $(+8 \%)$ and available water-holding capacity $(+6 \%)$ for both $\mathrm{C} 1$ and $\mathrm{C} 2$ compost rates compared to control (Tables 2 and 3; Fig. 1d, e).

\subsection{Fertilization treatment effects on poplar survival and growth}

Survival was quite high in 2008 (>94\%) and 2009 (>89\%) for all tested clones and treatments (results not shown). No significant treatment effect occurred on survival, except for clone $\mathrm{BxM}$ under $\mathrm{C} 1$ rate $(75 \%, p=0.048)$ due to deficient field maintenance in one subplot and associated aggressive weedy competition.

As no statistical interaction occurred between fertilization treatments and clones for height, the three clones were pooled together to study fertilization effect. Generally, mineral fertilization treatments improved tree growth compared to control, while compost treatments had intermediate effects (Tables 2 and 3; Fig. 2). In both 2008 and 2009, tree height was greater in M2 than in control and both compost rates; however, tree height in M1 was greater than in the control treatment but similar to both compost rates (Fig. 2a). For basal diameter, a significant interaction occurred between fertilization treatment and clone. It was the only studied variable for which clone interacted with fertilization treatments. Indeed, treatment effect on basal diameter was significant only for the largest clone, where mineral fertilization induced greater diameter growth compared to control and compost treatments (Tables 2 and 3). The fertilization effect on dominant shoot basal diameter was similar for all clones in 2009 (Tables 2 and 3), where trees in M2, M1, and C2 treatments had greater diameters compared to trees in $\mathrm{C} 1$ and T (Fig. 2b).

The three clones used had different overall height and basal diameter (Tables 2 and 3, results not shown); clone $\mathrm{MxB}$ was the tallest and the largest, while clone BxM had the smallest height, and clone DxB the smallest basal diameter.

\subsection{Fertilization treatment effects on biomass allocation}

As no statistical interaction occurred between fertilization treatments and clones for the biomass allocation parameters, the three clones were pooled together to study fertilization effect. Fertilization treatments had no effect on poplar biomass and other related variables (leaf area, leaf number, SLA, LAR, LMR, SMR, and RMR) at the end of the first growing season (2008; Tables 2 and 3). In the second year, however, mineral fertilization treatments increased leaf and root development, as well as total biomass (Fig. 3a, b) of all clones compared to control. The effects of compost treatments were generally intermediate. The same year, total leaf area increased with M2 $\left(1,476 \mathrm{~cm}^{2}\right)$ compared to both control and compost treatments $\left(<962 \mathrm{~cm}^{2}\right.$; results not shown). Compost at $\mathrm{C} 1$ rate increased specific leaf area of all clones compared to all other treatments (Fig. 3a).The M2 treatment increased the biomass of adventitious roots with diameter smaller than $5 \mathrm{~mm}$ developed on the $15-\mathrm{cm}$ pruned shoot (Fig. 3b) compared to control and both compost rates. For total leaf biomass, total biomass, and total root biomass, the effects of $\mathrm{C} 2$ was intermediate between control and M2, showing compost rate effect (Fig. 3). Compost amendment did not increase biomass allocation to roots, while mineral fertilization at rate M2 decreased it compared to control (Fig. 3c). Mineral fertilization at both rates increased leaf biomass ratio compared to both compost rates; but none of 
the fertilization treatment was significantly different from the control for this parameter (Fig. 3c).

The three clones had different biomass allocation patterns (Tables 2 and 3, results not shown); clone MxB allocated more biomass to its roots with the greatest RMR among clones in 2008 and 2009, and had the greatest root biomass in 2009. Clone DxB allocated more biomass to its leaves with the greatest LMR among clones in 2008 and 2009. Clone DxB also had the greatest LAR in 2008 and the largest leaves in 2009.

\subsection{Fertilization treatment effects on poplar nutrition}

As no statistical interaction occurred between fertilization treatments and clones for the nutrition parameters, the three clones were pooled together to study fertilization effect. In 2008 , the compost and mineral fertilization treatments induced opposite results for $\mathrm{N}$ and major cations in leaves of all clones; but none of these treatments showed a significant response relative to the control (Tables 2 and 3, Fig. 4a). M1 and M2 increased total $\mathrm{N}$ concentration in leaves compared to compost application. On the other hand, mineral fertilization decreased $\mathrm{K}$ (M1 and M2), Ca (M2), and $\mathrm{Mg}$ concentrations (M1 and M2) compared to the compost treatments (Fig. 4a). There was no effect of treatments on foliage P concentration (Fig. 4a). The second year, fertilization treatments effect, especially compost treatments, was generally significant compared to the control (Tables 2 and 3, Fig. 4b). $\mathrm{N}$ foliar content was higher in $\mathrm{C} 1$ and M2 compared to control and M1. Both compost treatments increased $\mathrm{P}, \mathrm{Ca}$, and $\mathrm{Mg}$ in leaves compared to control and mineral treatments. Finally, M1 and M2 decreased $\mathrm{K}$ foliar content compared to the other treatments (Fig. 4b).

3.5 Fertilization treatment effects on poplar ecophysiology

In $2009, \delta^{13} \mathrm{C}$ of leaves was less negative in both $\mathrm{C} 1$ and M2 treatments ( -28.5 for both treatments) compared to the control (-29.2) and M1 (-29.1) for all clones, C2 being intermediate (-28.7; Tables 2 and 3). Clone MxB also appeared more water stressed than the other clones with less negative $\delta^{13} \mathrm{C}$ values (Tables 2 and 3, results not shown).

\section{Discussion}

The application of mineral fertilization near the root system, especially at rate M2, was the most efficient approach to increase poplar growth, even in our N-rich soil (4 $\mathrm{Mg} \mathrm{ha}{ }^{-1}$ or $0.27 \%$ of soil DM) compared to agricultural soils classified as fertile in other studies (e.g., 


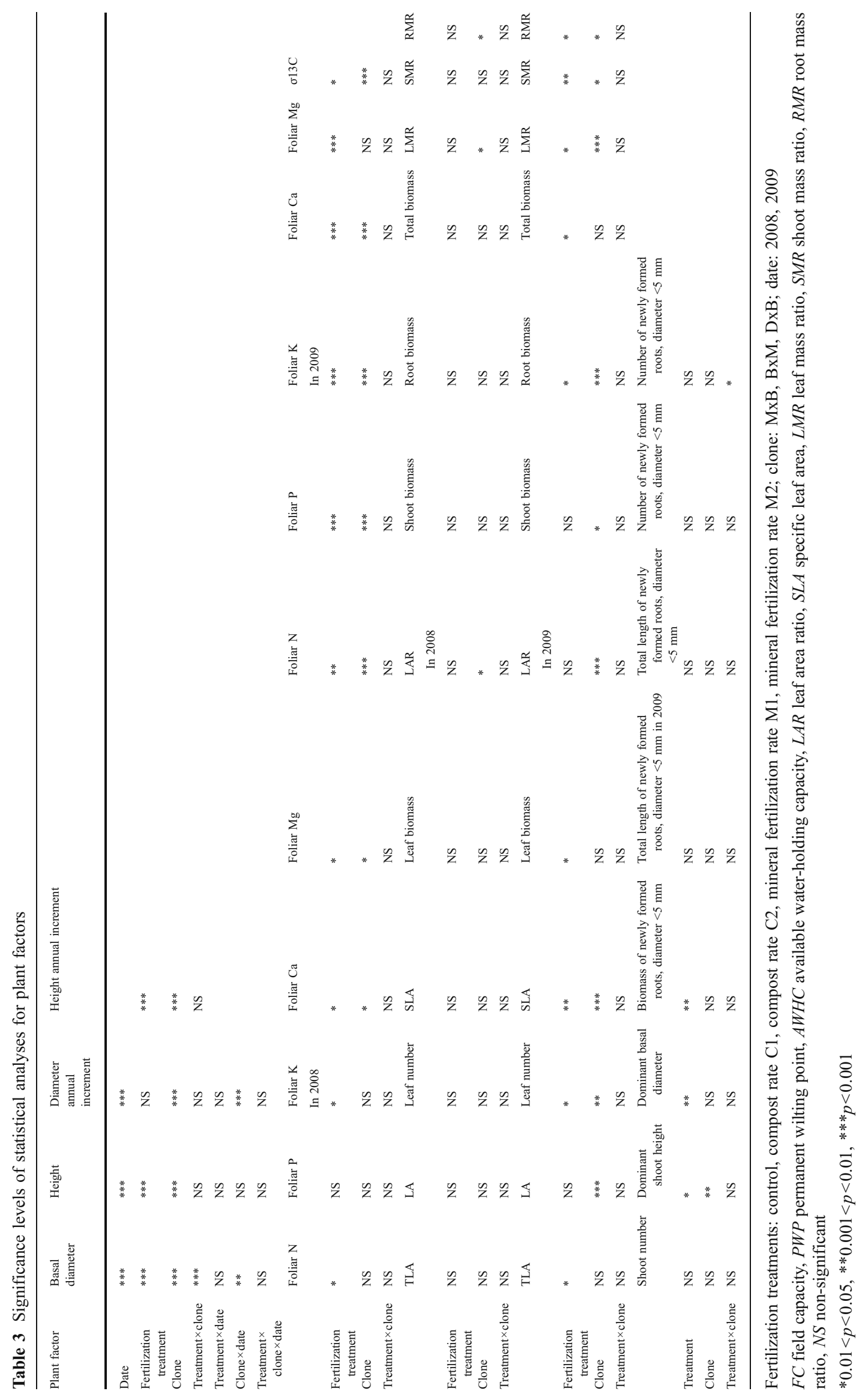


Fig. 1 Comparison of soil parameters (total $\mathrm{N}(\mathbf{a})$, total $\mathrm{P}$ (b), exchangeable $\mathrm{K}$ (c), field capacity (d), and available water-holding capacity (e)) before compost amendment (June 2008), the first growth season (August 2008), and the second growth season (July 2009) among the control (T) and the two compost rates $(\mathrm{C} 1$ and $\mathrm{C} 2)$. Mean $(N=4)$. Bars denote SE; $* 0.01<p<0.05$, $* * 0.001<p<0.01, * * * p<0.001$. $D M$ dry matter
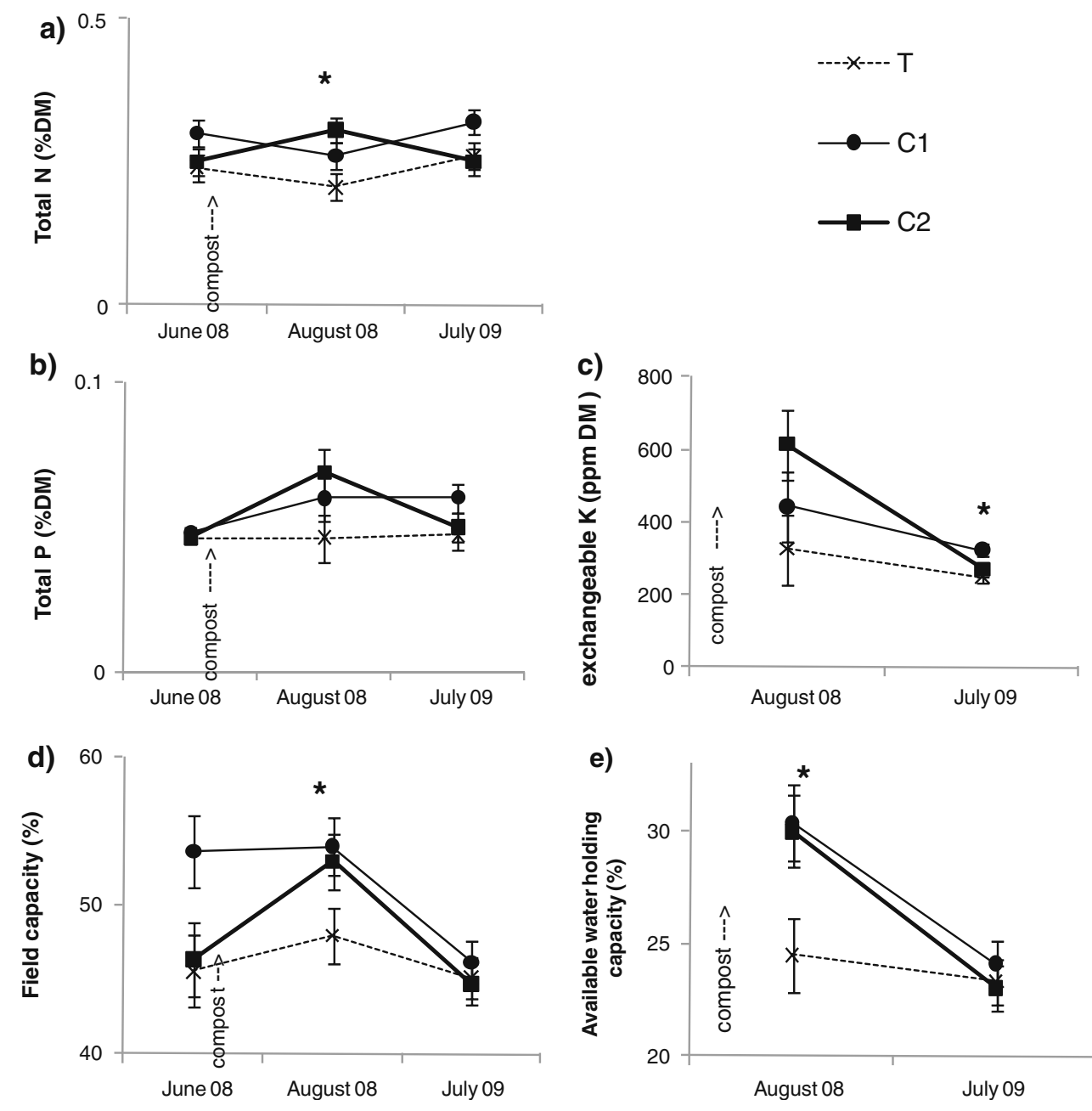

Guillemette and DesRochers 2008; Hansen et al. 1988). The soil of the experimental site had high clay content, which can be associated with the high cation exchange capacity and nutrient content. Also, weed plowing for site preparation and maintenance likely provided a source of fresh and rapidly decomposable organic matter in the experimental soil. Mineral fertilization at rate M2 provided sufficient N source to increase poplar growth for both years. Despite amendment rates $(99 \mathrm{~kg}$ of total $\mathrm{N}$ per hectare for C1) higher than rates of slow-release fertilizers reported by others $\left(50 \mathrm{~kg} \mathrm{Nha}^{-1}\right)$ to induce near-maximum growth potential for willow (Adegbidi et al. 2003) and hybrid poplar (Coleman et al. 2004) plantations, the poplars grown with compost amendments had intermediate growth values between control trees and trees that were fertilized with mineral $\mathrm{N}$ and $\mathrm{P}$.

As the $\mathrm{N}$ content in leaves of all trees in our experiment $(1.5 \%-2 \%)$ was low compared to optimal rates reported by Hansen et al. (1988), N fertilization was probably responsible for growth enhancement. Similarly, the N/P ratios of our trees in the first year were all lower than 10, which suggested N deficiencies according to Güsewell (2004).
Indeed, $\mathrm{N}$ is often the most limiting nutrient for poplar growth in all regions, especially under boreal cool climatic conditions due to slower mineralization rates (Stanturf et al. 2001). This slow mineralization rate may be responsible for compost poor effect on poplar growth. In addition, it seems that the 2 years of maturation of our manure compost conferred it a low decomposability and a low $\mathrm{N}$ mineralization rate $(1.8 \%$ of total $\mathrm{N})$ probably due to high humic acid content (N'Dayegamiye et al. 1997). On the other hand, the low $\mathrm{C} / \mathrm{N}$ ratio of control soil implied a rather elevated $\mathrm{N}$ mineralization rate and allowed it to be a good source of $\mathrm{N}$ for the trees. This could explain why foliar $\mathrm{N}$ content of trees and associated growth in compost-amended plots were similar to those of control plots in 2008 .

Soil disking twice a year may have incorporated the compost down to the 20-25 first centimeter of the soil, diluting its effects in the sampled $15 \mathrm{~cm}$ layer for soil analyses in favor of the deeper mineral soil. This could explain the inexistent increase of total $\mathrm{P}$ in soil after amendment.

Early growth of trees has seemingly been delayed in the first year in every treatment, which suggests that compost 
Fig. 2 Comparison of trees height in 2008 and 2009 (a), and dominant shoot basal diameter in August 2009 (b) among the five fertilization treatments ( $T$ control, $C 1$ and $C 2$ compost rates, $M 1$ and $M 2$ mineral fertilization rates) for all clones. Mean $(N=84-96$ for height, $N=12$ for diameter). Bars denote SE. Treatments that do not differ at the 0.05 level are underlined with the same letter $(a>b>c)$

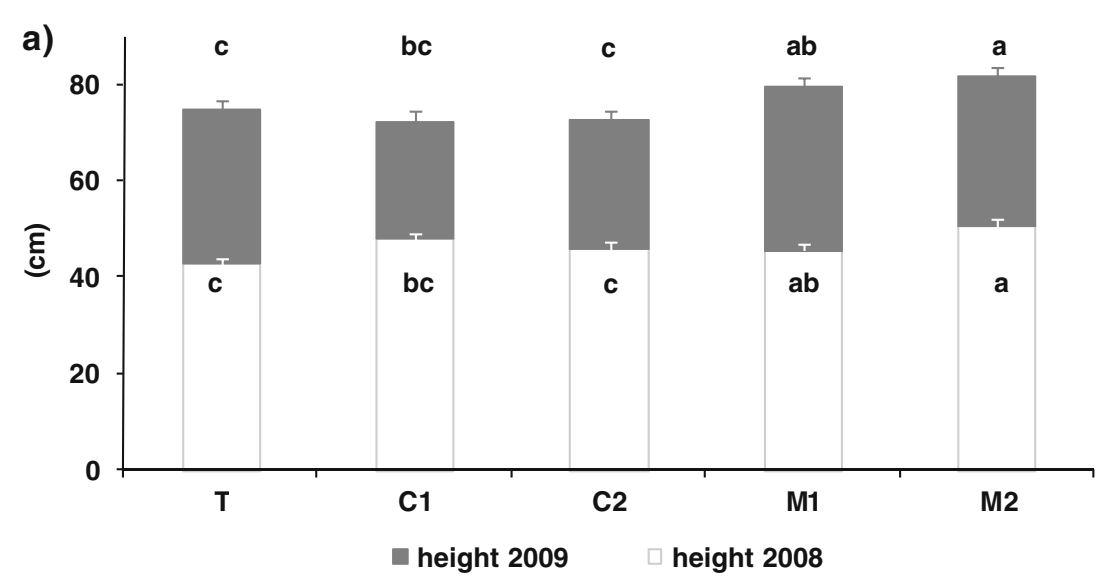

b)

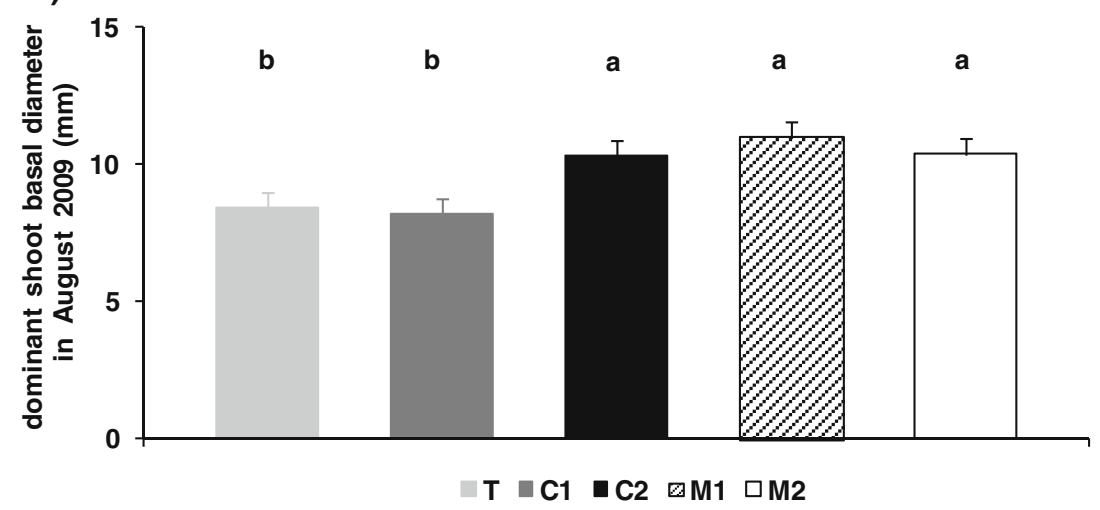

or mineral fertilization did not increase early growth rates and establishment. On average, the height annual increment of the trees (means of 0.47 and $0.28 \mathrm{~m}$ in 2008 and 2009, respectively) was $50 \%$ lower the first year than those found by DesRochers and Tremblay (2009) for the same type of tree material (rootstock with pruned stems) in the same region of Canada but similar for the second year. However, the M2 treatment-positive effect on poplar growth showed that placed fertilization was efficient to provide nutrients. This highlights the importance of fertilizer delivery mode in poplar plantations to increase nutrient availability to planted trees (van den Driessche 1999).

The second year, fertilization at rate M2 had a positive effect on leaf development and total biomass. Total leaf area is generally closely correlated with total biomass production and can be considered as a determinant of productivity in poplar. Similar to growth, this positive effect is probably related to $\mathrm{N}$ fertilization that improved foliage $\mathrm{N}$ concentration. This shows the beneficial effect of placed fertilization that allows roots to absorb $\mathrm{N}$ more easily in compact clay soils even if the soil is rich in $\mathrm{N}$.

Contrary to our expectations, compost treatments did not increase root development as suggested in other studies (Pagliali et al. 1981). As most root growth occurs in the fall (Isebrands and Nelson 1983), tree sampling for biomass measurements in August may have been too early to observe a treatment effect on biomass allocation, especially for roots. On the opposite, we found the M2 treatment to have stimulating effects on fine root development compared to compost and control treatments. Yet, placed mineral fertilization has been shown to decrease root system development of seedlings (Jacobs et al. 2004). However, despite the fact that new unsuberized roots generally permit a more efficient uptake of water than suberized roots (Grossnickle 2005), mineral fertilization also increased water stress of trees with higher $\delta^{13} \mathrm{C}$. This result could be related to lower arbuscular mycorrhizal colonization of roots fertilized with mineral fertilizers (Gryndler et al. 2006) that could decrease water absorption of M2 trees despite increased fine roots development. But the greater leaf area that developed in the M2 treatment in 2009, associated to root biomass allocation decrease may also have rendered the trees more drought sensitive by increasing their transpiring to absorbing surface. Greater leaf area of $\mathrm{N}$ fertilized poplars can predispose them to greater water stress, as well as increased leaf loss and decreased water potentials (Harvey and van den Driessche 1999). In addition, decreased $\mathrm{K}$ in leaves of trees with mineral fertilizers could also be responsible for greater water stress as $\mathrm{K}$ is 
Fig. 3 Comparison of tree biomass parameters in August 2009 (a specific leaf area, total biomass and leaf number; b biomass of leaves, roots, and newly formed roots whose diameter is lower than $5 \mathrm{~mm}$; c leaf, shoot, and root mass ratios) among the five fertilization treatments ( $T$ control, $C 1$ and $C 2$ compost rates, $M 1$ and $M 2$ mineral fertilization rates) for all clones.

Mean $(N=12)$. Bars denote SE.

Treatments that do not differ at the 0.05 level are noted with the same letter $(a>b>c)$ a)

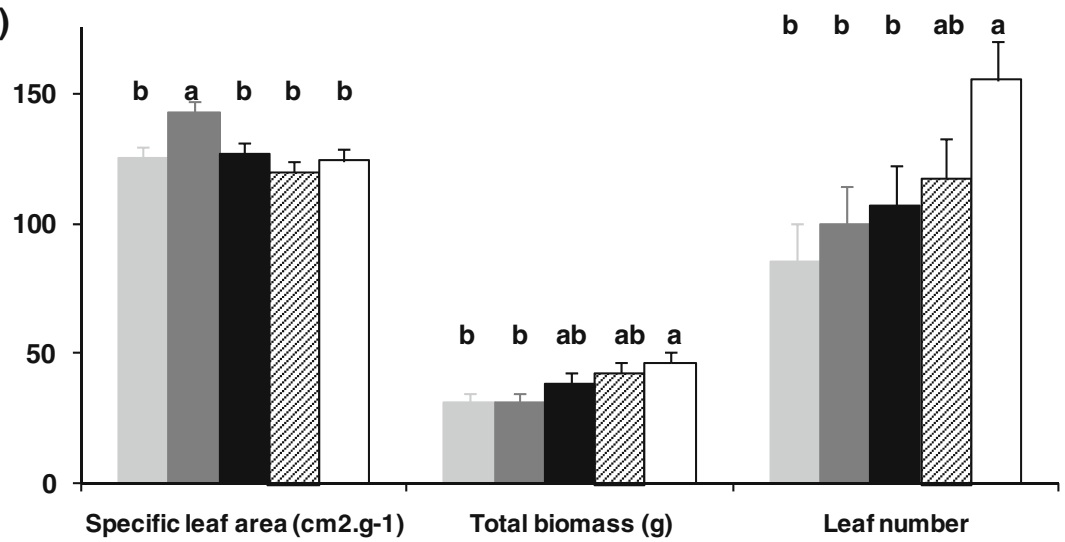

b)

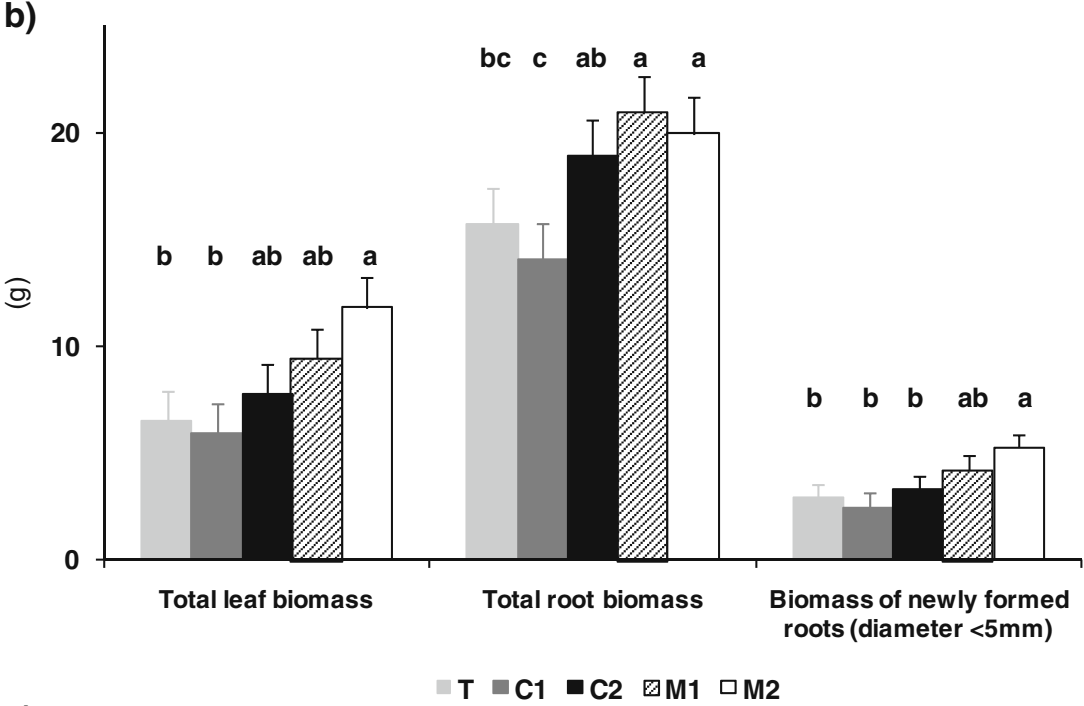

c)

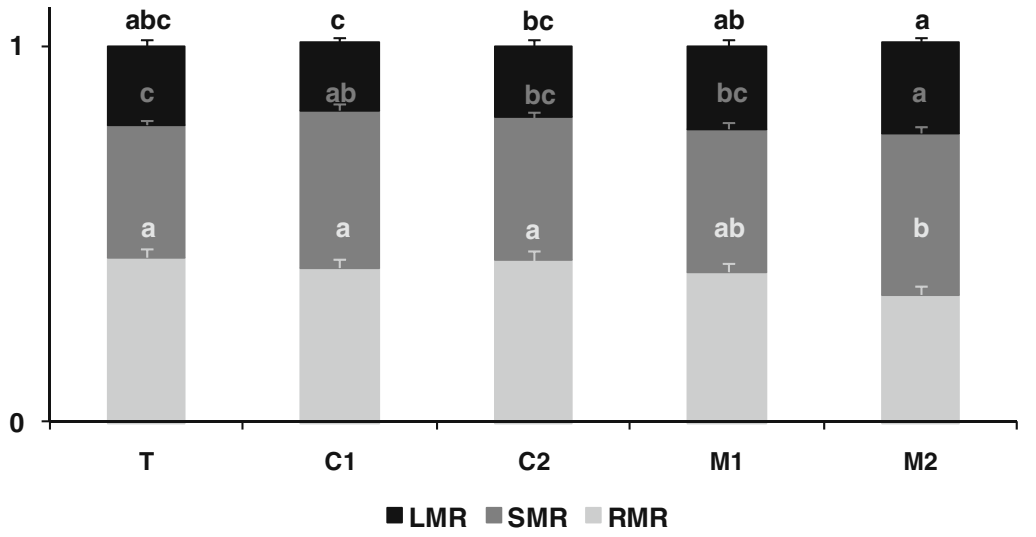

known to play a key role in the water cycle of higher plants (Marschner 1995).

The annual height increment of trees grown on compost was lower than control and mineral fertilization treatments the second year. As a result, higher $\mathrm{N}$ foliar content in $\mathrm{C} 1$ leaves compared to other treatments (except M2) this year showed $\mathrm{N}$ accumulation rather than better $\mathrm{N}$ availability in soil. Here again, the higher $\mathrm{N}$ concentration of leaves could be related to the drought stress increase found in these trees (less negative $\delta^{13} \mathrm{C}$ ). But the higher SLA of the trees grown on $\mathrm{C} 1$ treatment, implying greater transpiring area, could also explain their greater drought stress. Mineral P fertilization had no effect on foliar $\mathrm{P}$ concentration whereas both compost rates increased it (Fig. 4). This result could also be related to $\mathrm{P}$ accumulation in leaves due to poorer growth compared to mineral fertilization treatments. However, it is also well-known that phosphates have low solubility in clay soils (Marschner 1995) and this may 
Fig. 4 Comparison of trees foliar content $(\mathrm{N}, \mathrm{P}, \mathrm{K}, \mathrm{Ca}$, and $\mathrm{Mg}$ ) in August 2008 (a) and 2009 (b) among the five fertilization treatments ( $T$ control, $\mathrm{Cl}$ and $C 2$ compost rates, $M 1$ and M2 mineral fertilization rates) for all clones. Mean $(N=12)$. Bars denote SE. Treatments that do not differ at the 0.05 level are noted with the same letter $(a>b)$
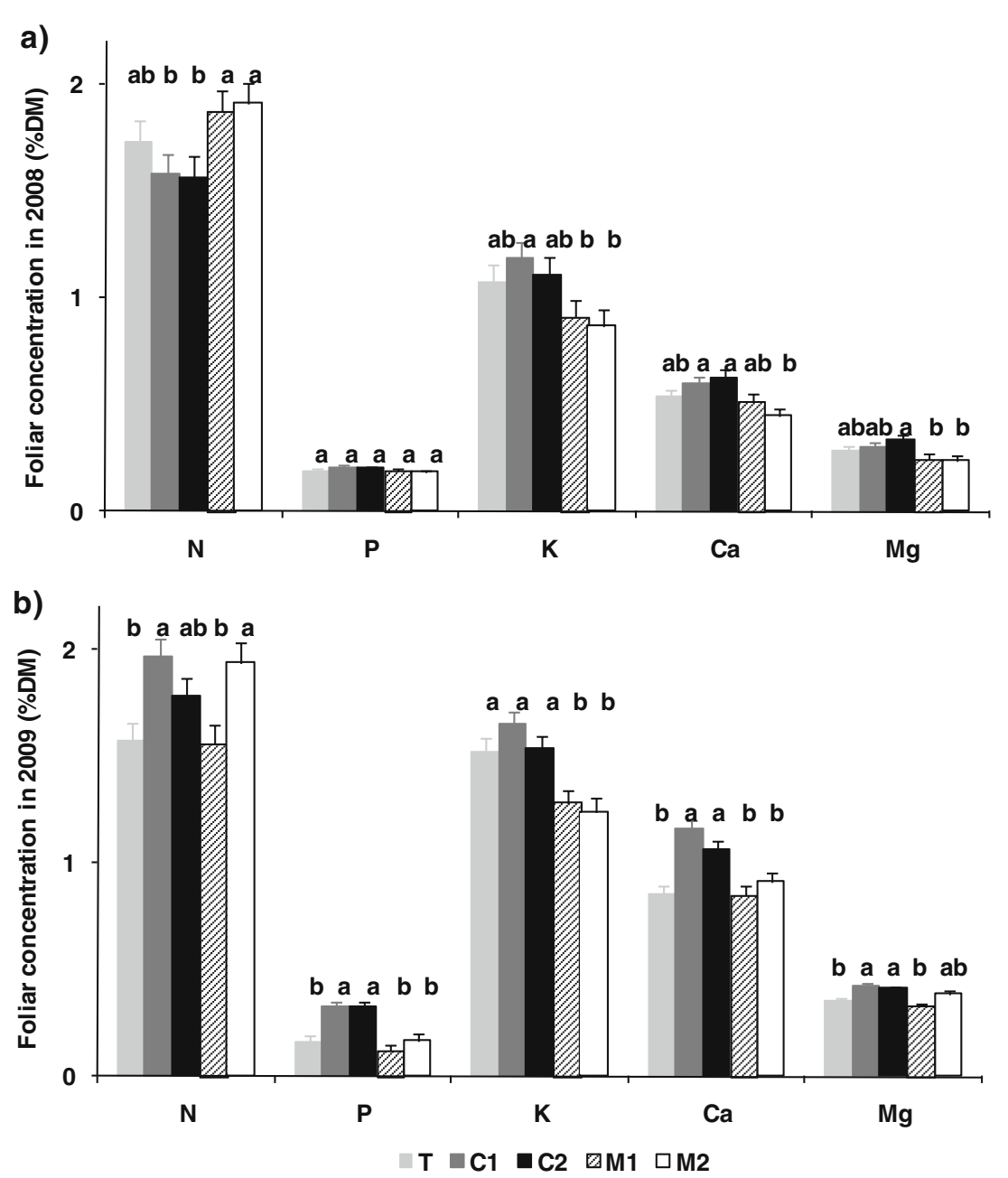

explain why mineral $\mathrm{P}$ fertilization had a poor effect on foliar $\mathrm{P}$ concentration. On the other hand, the compost provided stable organic matter to soil that may have increased $\mathrm{P}$ availability (Xie et al. 1995). Compost increased $\mathrm{Ca}$ and $\mathrm{Mg}$ in leaves compared to mineral fertilization (both years) and control (second year). However, despite a possible improving effect on tree growth of these elements, $\mathrm{Ca}$ and $\mathrm{Mg}$ deficiencies are rarely observed in poplar plantations except maybe on very poor sandy soils (Stanturf et al. 2001) and the compost beneficial effect on their concentration may be of minor importance.

Compost improved soil structure in 2008 by increasing water-holding capacity and field capacity compared to other treatments (Fig. 1). However, there was no difference among fertilization treatments for instantaneous water use efficiency in the summer of 2008. Indeed, the planting stock type used (rootstock with pruned stems) is one of the most suitable to reduce water stress by synchronizing leaf and root development (DesRochers and Tremblay 2009). The second year, this effect on soil water-retention properties had disappeared; repeated disking of the site for maintenance may have disrupted compost organic matter and soil particle aggregates.

\section{Conclusion}

Our results may be generally applicable to hybrid poplar plantations on similar soils because there were few interactions between fertilization treatment and clone among all parameters studied, despite morphological and parentage differences between the planted hybrids. Therefore, we recommend the use of placed $\mathrm{N}$ mineral fertilization (30 $\mathrm{g}$ of ammonium nitrate) near the root system rather than manure compost use to improve poplar establishment in the first years following plantation for similar sites with appropriate $\mathrm{P}$ content. Furthermore, added $\mathrm{K}$ fertilization may be of great interest to limit nutrient imbalances and $\mathrm{K}$ decrease in leaves of fertilized trees. However, in zones next to an animal feedlot, compost manure could represent a viable and cheaper alternative even if mineral fertilizer gave the greatest responses. 
Acknowledgments This research was funded by the Quebec Ministry of Natural Resources and Wildlife (Volet1 and Volet 2 programs), Norbord, Alpac, Natural Resources Canada and the Natural Sciences and Engineering Research Council of Canada through a Collaborative and Research Development grant to AD.We also thank MRC Abitibi, Réseau Ligniculture Québec, Centre d'Étude de la Forêt, and Chaire CRSNG-UQAT-UQAM en Aménagement forestier durable.

\section{References}

Adegbidi HG, Briggs RD, Volk TA, White EH, Abrahamson LP (2003) Effects of organic amendments and slow-release fertilizer on willow biomass production and soil chemical characteristics. Biomass Bioenergy 25:389-398

Cassel, D.K., and Nielsen, D.R. (1986) Field capacity and available water capacity. In: Methods of soil analysis. Part 1-physical and mineralogical methods. Agronomy Series No 9. ASA, Inc., SSSA, Inc: Madison, WO, USA. pp. 901-926.

Coleman MD, Friend AL, Kern CC (2004) Carbon allocation and nitrogen acquisition in a developing Populus deltoides plantation. Tree Physiol 24:1347-1357

DesRochers A, Tremblay F (2009) The effect of root and shoot pruning on early growth of hybrid poplars. For Ecol Manage 258:2062-2067

Dickmann DI, Isebrands JG, Eckenwalder JE, Richardson J (2001) Poplar culture in North America. NRC Research Press, Ottawa, ON, Canada, p 397

Environment Canada, 2004. National climate archives. Available from: http://climate.weatheroffice.ec.gc.ca/index.html. Accessed 17 May 2011

Food and Agriculture Organization of the United Nations (2009) Available from: http:/www.fao.org/forestry/plantedforests/en/. Accessed 17 May 2011

Grigal DF (2000) Effects of extensive forest management on soil productivity. For Ecol Manage 138:167-185

Grossnickle SC (2005) Importance of root growth in overcoming planting stress. New For 30:273-294

Gryndler M, Larsen J, Hršelová H, Řezáčová V, Gryndlerová H, Kubát J (2006) Organic and mineral fertilization, respectively, increase and decrease the development of external mycelium of arbuscular mycorrhizal fungi in a long-term field experiment. Mycorrhiza 16:159-166
Guillemette T, Desrochers A (2008) Early growth and nutrition of hybrid poplars fertilised at planting in the boreal forest of western Quebec. For Ecol Manage 255:2981-2989

Güsewell S (2004) N:P ratios in terrestrial plants: variation and functional significance. Tansley review. New Phytol 164:243-266

Hansen EA, McLaughlin RA, Pope PE (1988) Biomass and nitrogen dynamics of hybrid poplar on two different soils: implications for fertilization strategy. Can J For Res 18:223-230

Harvey HP, van den Driessche R (1999) Nitrogen and potassium effects on xylem cavitation and water-use efficiency in poplars. Tree Physiol 19:943-950

Isebrands JG, Nelson ND (1983) Distribution of $\left[{ }^{14} \mathrm{C}\right]$-labelled photosynthates within intensively cultured Populus clones during the establishment year. Physiol Plant 59:9-18

Jacobs DF, Rose R, Haase DL, Alzugaray PO (2004) Fertilization at planting impairs root system development and drought avoidance of Douglas-fir (Pseudotsuga menziesii) seedlings. Ann For Sci 61:643-651

Larchevêque M, Baldy V, Montès N, Fernandez C, Bonin G, Ballini C (2006a) Short-term effects of sewage sludge compost on a degraded Mediterranean soil. Soil Sci Soc Am J 70:1178-1188

Larchevêque M, Ballini C, Korboulewsky N, Montès N (2006b) The use of compost in afforestation of Mediterranean areas: effects on soil properties and young tree seedlings. Sci Tot Environ 369:220-230

Marschner H (1995) Mineral nutrition of higher plants, 2nd edn. Academic, London, UK, p 889

N'Dayegamiye A, Royer R, Audesse P (1997) Nitrogen mineralization and availability in manure composts from Quebec biological farms. Can J Soil Sci 77:345-350

Pagliali M, Guidi G, La Marca M, Giachetti M, Lucamente G (1981) Effect of sewage sludge and composts on soil porosity and agregation. J Environ Qual 10:556-561

Stanturf JA, van Oosten C, Netzer DA, Coleman MD, Portwood CJ (2001) Ecology and silviculture of poplar plantations. In: Dickmann DI, Isebrands JG, Eckenwalder JE, Richardson J (eds) Poplar culture in North America. NRC Research Press, Ottawa, Ontario, Canada, pp 153-206

van den Driessche R (1999) First-year growth response of four Populus trichocarpa $\times$ Populus deltoïdes clones to fertilizer placement and level. Can J For Res 29:554-562

Xie XH, MacKenzie AF, Xie RJ, Fyles JW, O'Halloran IP (1995) Effects of ammonium lignosulphonate and diammonium phosphate on soil organic carbon, soil phosphorous fractions and phosphorous uptake by corn. Can J Soil Sci 75:233-238 